\title{
“DAMN 'EM, GOD BLESS 'EM!": WHITMAN AND TRAUBEL ON THE MAKERS OF BOOKS
}

\author{
GaRy SchMidgall
}

ONE OF MY BEST New York friends is Tom Tanselle-that is, G. Thomas Tanselle, the long-time recently retired Senior Vice President of the Guggenheim Foundation, Melville scholar and editor, and, most importantly, the dean of American textual scholars and scholars of the book. He is the Fredson Bowers of his generation; indeed, he has authored, among many other studies, the definitive book on Bowers, whose foray into Whitman manuscript studies exactly fifty years ago proved so illuminating. ${ }^{1}$ Tom was among the first to receive from me a copy of Intimate with Walt, my collection of highlights from the nine volumes of With Walt Whitman in Camden, Horace Traubel's champion venture into oral history. His reaction to the book was complimentary, but he did draw my attention rather frostily to one sentence that stuck in his craw. It is the first sentence of my headnote to the chapter gathering Walt's observations about the design and making of his last books. "If there is one regular topic of conversation in Traubel's pages that sometimes does more than threaten to become tedious," I wrote, "it is the interminable debate and dealings with all the 'publisherial' artisans and contractors responsible for producing November Boughs (1888), the nine hundred-page Complete Poetry and Prose (1888), and the 'deathbed' Leaves (1892)."'

As if talk about book-making could ever become tedious to a true bibliophile! When I accepted Ed Folsom's invitation to take part in the Whitman Making Books symposium, I immediately informed Tom that I would be participating in a veritable orgy of book-making talk, saying this would be penance for my faux pas. When I saw him recently, he could have expressed the fond hope that my presentation would not be found tedious. But, being a gentleman and a bookman, he didn't.

Let me hasten to add, however, that I am well acquainted with tedium. Given the right motivation, I have found I have a remarkably high tedium threshold, one that verges on the positively saintly. I did not set out to prove this by spending (I will venture) more time in the company of Horace Traubel than any person now breathing on the planet, but that is the upshot. For, after moving a lot of rock to get at 
the nuggets of gold in those nine volumes of With Walt Whitman in Camden, I found myself a few years later reading from stem to stern all 352 issues of Traubel's liberal/socialist/avant-garde journal called The Conservator, pronounced to rhyme with "radiator," sonar-scanning (I am changing my image) for the best Whitmaniana he poured into it over the course of thirty years. By last summer Ed knew that the tedious part of my two projects was largely behind me. ${ }^{3} \mathrm{He}$ suspected, correctly, that I might now enjoy sharing some of my favorite glimpses into Whitman's book-making talk. Think of me, then, like a somewhat weary treasure hunter eager, after long days criss-crossing the grid, to show off some of his barnacle-encrusted doubloons plucked from the ocean floor.

It cannot hurt to begin with the obvious, and that is the fact that making a book is painstaking work. As Walt summed up to Horace a year before he died, "I do not think even intelligent people know how much goes to the making of a book: worry, fret, anxiety-downright hard work" (8:82). ${ }^{4}$ Now, here I am tempted to stop and add: "Walt you don't even know the whole story-you never had to make an index!" (I've made it a point of honor to do my own indexes, and just recently produced my seventh one, for the Conservator anthology. A lot more fretting goes into the making of a proper index than even intelligent people suspect. Well, I had to get that off my chest.)

The second obvious and well-known fact worth repeating is that Whitman threw himself eagerly into this hard work of book-making, doubtless to the regular dismay and aggravation of his printers. "I like to supervise the production of my own books," he said; "I have suffered a good deal from publishers, printers-especially the printers, damn 'em, God bless 'em! The printer has his rod, which has often fallen on me good and powerful" (1:194). On another occasion he remarks, "I am sensitive to technical slips, errors - am as ready as anyone to have everything shipshape... I abhor slouchy workmen - always admonish them in offices doing my work: don't put on a slouchy printer" $(2: 237)$. What made Whitman a relentless "printerial" nudge, of course, was his professional experience: he knew well his brevier from long primer and small pica. 5 "Having been a printer myself," he told Traubel, "I have what may be called an anticipatory eye-[I] know pretty well as I write how a thing will turn up in type-appear - take form" (5:390). And so there are several comments by Traubel about Whitman in the conversations like this one concerning November Boughs: "He is stubborn about having his punctuation, abbreviation and general arrangement strictly followed" (1:358). 
Publishers in my experience are usually thrilled when authors butt out of technical and design decision-making, but Whitman's printers had no such luck. He gives the reason for this, perhaps, in this astonishing remark he made in 1889: "I sometimes find myself more interested in book making than in book writing: the way books are made-that always excites my curiosity: the way books are written - that only attracts me once in a great while" $(4: 233)$. This sentiment may explain why Whitman was disgusted by the contents of Charles Woodbury's collection of reminiscences, Talks with Ralph Waldo Emerson (1890), but was delighted by the physical book and called it "undoubtedly a typographical pleasure; I have enjoyed that without break" (7:102).

Whitman's mixed feelings about his book-makers-“damn 'em, God bless 'em!" - is certainly borne out by his private comments on them. "What a cute [i.e. acute] — devilishly cute-lot the publishing wolves are" he fumes one day, and on another he admits, "Authors always growl about publishers, probably with a good deal of reason" $(2: 176 ; 1: 168)$. A lifetime of such growling was summed up by Whitman from a Mickle Street parlor chair in 1890: "No man has suffered worse than I have from editors who insist they can read my proofs better than I can and printers who insist that they know the location of the commas better than I do." Then he added morosely, "It is always the particular error you don't want to happen that does happen, anyhow" (6:320).

To be sure, Walt was also willing to grant that authors sometimes growl too much about publishers. One day he said, referring to David McKay, Whitman's last favored (and most often discussed) publisher, that several friends had warned him, "You'll have to watch McKayhe's foxy-he'll do you up." When Whitman asked why they singled out McKay, he says he was told: "We don't-he is a publisher: that is enough: all publishers do it" (1:424).

In fact, although the shrewd Scotsman McKay was combative with the poet on many issues - he hated, for example, the cherished hope of Walt and Horace to put out a cheap, 50-cent Leaves-Whitman grudgingly respected him. Sending Horace off to meet with him, Walt described McKay thus: "Dave is a canny Scotchman - thick-set, bluff, bustling, businessy. . . . I have found Dave shrewd but at all times scrupulous" (1:168). A week later Walt added that McKay was "honest: crude, almost crusty sometimes-but square" (1:206). Presumably alluding to McKay's "businessy" mien, Whitman afterward spoke of him as "the coolest of mortals, who don't seem to have any fire at all in him" (6:263).

Whitman was a vowed enemy of dogmatism in so many ways; it is no surprise that he also bridled, throughout his career, at what he called "printerial dogmatism" (6:328). The tiniest printerial initiatives could set Whitman off. When McKay added the 'u' in "pourtrayal" 
in Camden's Compliment to Walt Whitman, he laughed and said, "no, indeed, we do not want this: this was a fashion forty years ago, but we do not make much of it this year. It is a peculiarity of printers to insist and insist. If there had been something in that page particularly needing to be seen-fixed-eluding us-he would not have seen it" $(6: 17)$. Probably from the beginning of book time, sanguine authors have carped about timid print runs. When Whitman was told McKay planned 500 copies of Camden's Compliment, he "laughed brightly" and said, "He ought to print more-I should say, a thousand, at least" $(6: 17)$. Six weeks later, Horace asked whether an inexpensive "popular" edition of Leaves "would go," and Walt replied, "I feel sure . . that if a hustler got hold of Leaves of Grass the book would make the fur fly in many places it don't touch at all. And Dave is not a hustler-I know that well enough" $(6: 130)$.

There are numerous manifestations in the conversations of the eternal tension between authorial ideals and the printer's bottom line, especially when the 1892 Leaves was in production. Walt caught the tension perfectly one day when he remarked, "Dave thinks I am inexcusably stubborn: so be it: Dave is inexcusably sensible" (4:427). Here is Walt in his stubborn vein: "Dave seems to forget that the making of the book to me only matured after stage upon stage of experience, thought-is not to be denied by the whim of a day or the fear that it may take the bottom out of his profits. The book is ours and we will hold the reins" $(8: 510)$. And generally the poet got his way. With the 'deathbed' nearly out of his hands for good, he could remark with a laugh, "Dave is a good fellow, and is inclined to humor me (has been, in fact, from the start), and I am inclined to be humored" (9:395). A few days later, Whitman preened about his upper hand, "Dave sometimes kicks a little at our pranks but always laughs and gives in" (9:410). A few months earlier, Traubel had recorded having a long talk with McKay about Whitman: "His affection for W. a good deal more than publisherial. Glad to know it, yet we have always known it, or suspected it" (9:158).

In any case, Whitman's very characteristic preference was to make personal contact with the artisans in a printing firm. One proprietor, named Bennerman, lost the November Boughs job because, as Whitman said, "he never wanted me to go upstairs into the composing room" (1:206). He explained to Traubel, "I don't like to deal too much with proprietors-I like to deal with men: it makes the work more like work, less like trade" (1:266). When he was told that the firm of George Ferguson was willing to give Horace the freedom of its office, the November Boughs deal was sealed, though the price of $\$ 1.30$ a page for plates in long primer-10-point font-was also attractive. Physically unable to do the schmoozing himself, Walt deputized Horace thus: "I want you to reach the workmen direct - treat the man who sets the type, the man 
who puts it into form, the man who runs the foundry: reach them, yes, with a dollar now and then. We will keep the troubled waters oiled" (1:206). Similarly, before Ferguson started work on the 900-page Complete Poems and Prose (referred to at Mickle Street as "the big book"), Walt charged Horace, "I want you to get and keep on good terms with the working printers" (1:266).

Though Whitman was complimentary about Ferguson's printing of the big book, suddenly slouchy work gave him fits. One day Horace brings by six sheet sets, and he records that Whitman "handled them in all ways-scanned, felt, ruminated" (5:158); then he bursts out, "Ferguson ought to be ashamed of himself-ashamed; it comes hard to send such printing over there [i.e. France] when they are always sending us such beautiful work." Horace says hearing this might make Ferguson mad, and Walt replies, suggesting a strategy of shaming him: "Well, we won't say it to make anybody mad-only say it out of justice, because it ought to be said. Oh! You may tell it to Ferguson that way-tell him we had aimed to send a copy abroad, to France, but we were ashamed to do so. If he is a true printer-and he is - he can have no deeper damnation to contemplate than that." Two weeks later, still furious, Whitman hoists up the flagpole the ultimate threat: "I want you to tell Ferguson again that I am not at all satisfied with the printing. ... If this printing is to be taken seriously, then I am afraid Ferguson has done his last printing for us" $(5: 221)$.

A common aggravation for Whitman was a printer's failure simply to follow directions. In his last years, however, his reaction was as often bemusement as fury. Traubel records that he was "amused" by the poet's "laughing condemnation" of proof that ignored his desiderata: "Why, he has in no sense followed me out. Has he eyes? Can he read? He could not have done worse if had set out to do everything the opposite of my instructions. Damn him! I'd say it to his face if he was here!" (6:156). Ten days later, after having trouble getting an advertising circular properly designed and set up, Whitman devised the following law of nature: "The printers all have their own ideas, too. I think some men are marked out from all eternity to be printers. . . . The printer is born [Traubel notes this is said "with a laugh"] to contradict us-to have his own way" $(6: 170)$.

On fairly infrequent occasions, Whitman let fly. Early in 1889, for example, Traubel arrived at Mickle Street with news that McKay continued to insist that a special reprinting of the 1881 Leaves for the upcoming Whitman birthday celebration be strictly limited in order to enhance their value (a press run of 600 was mentioned). Always resistant to anything with an exclusive aroma, Whitman vigorously squelched the notion. McKay thinks this is folly, and, when Traubel passes his news on to Whitman, the poet retorts: "You tell Dave that 
Walt Whitman has a right to make a damn fool of himself any time he pleases." Traubel: "Dave has his eye on the market: you have your eye on yourself: that's why you don't agree." Whitman: "Then to hell with the market, I say: when the market asks me to give up some principle I deem precious, I say, to hell with it." Such venting was apparently therapeutic, for Traubel observes, after the fury subsided, "He gets his tantrums now and then which immediately dissipate. His wrath has no venom in it" (4:99-101). As it turned out, McKay may have gotten his way in the end: a run of only 300 copies was produced.

One delinquent contractor, the stolid German binder Frederick Oldach, evoked several colorful outbursts of frustration. When Traubel reported, "We must be humble: Oldach can't be hurried," Whitman replied wryly, "I know: don't you see me on my knees? I admire his 'I'll do as I damned please' ways" (4:49). Several weeks later, Oldach succeeded in leaving Walt and Horace in tears-from laughter: "W. asked me to see Oldach again. 'Try to stir him up: tell him we want our book. My God! but he's a time-taker: he's slower'n pitch on a frosty morning! That book has been there about a month: it should be done: what must we do to get it?" Then Whitman had a bright idea: "Go there: don't hurt him: ram a needle in his ass - not far enough to hurt him —only far enough to wake him up." Traubel records that Whitman was "so funny about this I burst into a furious laugh. This broke him loose, too, and he ha-ha'd till the tears flowed down his cheeks like rain" (4:282).

On another occasion, the binder's lallygagging caused Whitman to repine, "Oldach is very elephantine," and Traubel shot back, "That's just the way he's described you: he said the other day that you were as slow a Dutch frigate turning a corner" (4:4-5). A short time later, Oldach sent word via Traubel that he was having trouble finding leather of "the right shade and color" for the Complete Poems $\&$ Prose. A droll exchange followed, with Whitman observing, "He is a great slow-coach, isn't he?" and Traubel riposted that Whitman was one too. This left the poet a "trifle irritated": "You don't mind saying impertinent things, do you, if they occur to you?" But then he backed off: "I suppose I am a snaily creature, take me for all in all." Traubel stood his ground-“And maybe that's why you hate the snail in Oldach"-and Whitman replied, "Yes: yes" (4:72).

But, as with most of his printerial adversaries, Whitman almost always turned the benign Quakerly cheek once the inky dust had settled; mostly, his grudges retired quickly. Mulling over Oldach's tendency toward irascibility, Whitman expressed an ultimately pacific modus operandi that seems to have ruled most all of his relations with his contractors: "Well, if he is mainly right, if his tendency is in our direction, if he finally comes round, we can forget the rest- the little tempests ... treating these as matters of course - to be expected, laughed over" 
(4:146). More than two years later, as he waited yet again for a tardy Oldach to produce bound copies (this time of the "deathbed" Leaves), Whitman could still give the binder the benefit of the doubt: "He is an honest, straightforward German, determined to do the best thing" (9:175).

There is one workman about whom I found not a discouraging word from Whitman: the proof-reader. The poet must have been a sharp-eyed one himself in his halcyon days, but in his last years of diminished capacity he knew well he depended upon his proof-readers. The day before he admitted to Horace that "I don't seem to be worth my weight in feathers," he wrote this to the proof-reader of the "big book": "My dear sir, I shall mainly have to depend on you - shall mainly have to rely on your judgment and the copy-I find my brain has no grip on the copy and proof-I have done the best I can-my head is sick and weak" (1:366).

There's real warmth in Whitman's several salutes to this unsung hero: "What a tribe the tribe of proofreaders is! . . . Who can do justice to the cute, keen intellects of men of this stamp - their considerate patience, far-seeingness" (4:490). On another day he observed, "He is an important critter-the most important, I often think, in the making of a book. It is easy enough to have good material . . . but to put all in its rightful place and order! -oh! that is another thing!" (8:82). Thirty years after the fact, Walt remembered by name his final proofreader for the 1860 Leaves: "Very few people know . . . what we owe to the indefatigable proof-reader. I knew one, Henry Clark, a man not of extraordinary appearance . . but a man who seemed the deeper, more expansive the more a fellow looked" (6:267). And how typical of the Whitman ethos are these words spoken as he autographed a title page of November Boughs for the proof-reader at his printer Bilstein's: "I have a great emotional respect for the background people ... the absentees, the forgotten: the shy nobodies who in the end are best of all" (3:12).

The Whitman conversations are of course also valuable for the many occasions on which the poet offers his aesthetic credos. Here's a summary one: "I often think that pica is, after all, my type: it is so ample, so satisfies the eye; and then I am inclined for quite narrow margins, plenty of ink, good genuine paper-the best stock. This goes a great way in all particulars" (7:97). The lack of a good splash of ink often aroused him: "Leaves of Grass looks better, reads better, is better, when black-inked-when the ink has not been spared" (7:402). Commenting on a copy of the big book, Whitman said Oldach's binding made it a "brave book": "Everything that Oldach did was square and true", but Ferguson's printing, he added, "that vexes me-that is by no means 
up to the mark - neither registered nor well inked. I should say, the ink not only very bad, but very sparingly used, too. . . . Oh no! Ferguson has not done us up well this time" (5:189). Oldach himself had earlier come under fire for poor inking on his cover for November Boughs: "It's all good but that lettering on the cover: that's weak pea-soup, dishwash. Oldach tried for his worst on that and succeeded" (2:364).

Early in the conversations, Whitman described his notion of a good-looking page: "My ideal book page is an open one-a wide open one: words broadly spaced, lines with a grin, page free altogether: none huddled" (1:266). His preference for narrow margins, expressed above, seems to contradict this ideal. When Traubel queried why he "resented margins in books," Whitman did not produce a very edifying answer (4:75). Several months later, Whitman offered this general rule for margins: "We want the margin the narrowest that comports with decency ... not as broad as [the printer] chooses but as close as he chooses: like the hair on the head of a prize fighter: close enough to get rid of superfluities but not close enough to expose the scalp" (4:468). Whitman also preferred top margins narrower than bottom ones. In a very detailed letter of instructions to Oldach, he requested "a little more white paper at bottom, \& less at top" (5:190), and ten weeks later, when the finished book arrived, Traubel records that Whitman "pounced on the pictures [i.e. the inlaid portraits of Whitman] and the fact that Oldach had not strictly followed his directions - given more margin at bottom than top-'An idea which I much fancy' " (5:403).

Being famously self-contradictory, however, Whitman could turn around and extol open space on a page. For example, on noting that the autobiographical preface to November Boughs ended at the foot of a page, he observed, "If I had been a little more vigilant I should have cut out five or six lines. I like chapters in books to end short of a page-it pleases my eye better so" $(1: 357)$. When Whitman saw a page too full later on in the volume, he expressed the urge to excise a few lines of verse. Traubel asked, "Don't you love your lines too much for that?" The reply: "No-not enough to let them spoil the page" (1:359).

Incidentally, having voted for open space, Whitman paradoxically never cottoned to the idea of a big folio Leaves. "Some of the fellows have been at me to produce a folio of the Leaves," he remarked one day, adding, "It is a favorite notion of Talcott Williams: to have a big broad page to save me as much as possible from breaking my long lines. But it is only a pleasant dream-it is impossible at present" (1:207). My guess is that neither Whitman nor Traubel wanted to go in the direction of a $\$ 5$ or $\$ 6$ book; their real cherished, but ultimately unfulfilled, desire was a cheap, compact, and complete edition for 50 cents or so. Even the 84 cents that McKay charged for the 1892 Leaves in a paper cover 
struck the poet as outrageous; he calmed down only when he was told that 35 of the 84 cents was his royalty.

Predictably, Whitman was too much of a democrat and partisan of the common reader to be comfortable with specimens of fancy design and presswork or luxurious paper and binding. When Traubel asked his views of William Morris's work, he granted the appeal of his craftsmanship, but finally abstained: "they are not books for the people: they are books for collectors." Pursuing the subject, Traubel then asked his opinion of medieval illuminated books, eliciting this book-making credo: "They are pathetic to me: they stand for some one's life-the labor of a whole life ... they are exclusive: they are made by slaves for masters: I find myself always looking for something different: for simple things made by simple people for simple people" $(4: 20)$.

In fact, Whitman often romanced with the idea of a true pocketbook Leaves. One day he summarized it thus, referring to one of the cherished books he owned as a youth: "I have long teased my brain with the visions of a handsome little book at last - like the Epictetus - a dear, strong, aromatic volume, like the Encheiridion, as it is called, for the pocket. That would tend to induce people to take me along with them and read me in the open air: I am nearly always successful with the reader in the open air" $(2: 175)$. More than a year later, Whitman chided himself for listening to advice discouraging a pocket Leaves: "I had it in my earliest years - that to put a book in your pocket and off to the seashore or the forest - that is an ideal pleasure. I was on the point of getting out a pocket edition of Leaves of Grass many years ago. A woman-and a very [a] cute one, too-objected... . People as a rule [she said] like to open books on center tables, in parlors, and so on and so on. I took entirely too much notice of it at the time-let the matter slide" (6:130). A few months later, Whitman observed, "There is a great satisfaction getting a cheap book-a soft book you can mush in your hands . . . a book you are not afraid to injure" (6:264). Once Traubel got a little testy about all the harping on a pocket Leaves, exclaiming, "It makes no difference about people's pockets: if you get the big book into their hearts your victory is sure" (4:159).

In addition to fancy Japan-papered and moroccoed Leaves, Whitman likewise objected to the notion of a "selected" Leaves: "Any volume of extracts," he ruled, "must misrepresent the Leaves" (1:283). But by early 1892 he was perhaps too weak to stand in the way of Arthur Stedman's plans to publish such a truncation. Still, he did rise from his bed, just two weeks before he died, to suggest the ideal title for such a volume: Leaves of Grass, Funior (9:537).

Now, as you might expect, I have saved some of my favorite and most appealing vignettes for last. One is a rare tiff between Whitman and 
Traubel evoked by a printer's lateness: "W. was rather cranky to-night. Jumped on me for not having some message from Ferguson. 'What the hell?' he asked two or three times. I got tired of hearing it and asked him: 'What the hell?' too. That made him laugh. I said: 'If I'm doing so miserable bad why don't you bounce me?' He looked indignant for a minute: then said: 'I couldn't: you wouldn't be bounced.' 'Then you better accept me the way I am.' I was a bit mad myself." Traubel adds, "We don't have many tiffs" (3:177-78). How did Walt then get back on Horace's good side? Well, by producing the famous oft-mentioned but long-lost letter from Van Rensellaer reporting that Abraham Lincoln once saw Whitman on a Washington street and commented, "Well, he looks like a man" (4:178-180). Then he gave the precious manuscript to a doubtlessly delighted Traubel to take home for safe keeping.

Another amusing conversation resulted when Traubel asked Whitman about November Boughs, "Do you notice that your title page specifies no place of issue? Did you intend that?" "No-I did not intend to omit it - neither did I intend to insert it. I wrote down what came into my head at the time." And so Traubel suggested, I presume with a smile, "Call it America: America is the place." Whitman laughed and replied, "Yes, but that would sound egotistic-make too much of a spread: one has to be careful of that" (2:534-35). Horace could have said impertinently (but didn't) that it was pretty late in the day for that scruple!

Traubel was close enough to needle Whitman, as he did one day when the poet pasted up a sample of the margins he wanted for November Boughs, saying "That may give them an idea-but I mainly leave it to them." To which Traubel responded, "What nonsense, Walt: you mainly leave it to nobody: you want it your way and you'll have it that way though the heavens fall." Traubel records that Walt smiled at this and said, "How did you find that out? You're damned cute-too damned cute to live!" (4:468).

And anyone who has known the pleasure of handling one's own book for the first time can share Whitman's glee at holding November Boughs for the first time: "W.'s eyes were large with desire. . . .When I exhibited my prize he exclaimed: 'Handsome! it completely satisfies me: that is the book-the real, living, undoubted book!'” Turning it over and over fondly and in a spirit of undisguised exhilaration. [Whitman:] 'Horace, the deed is done. My blood, your blood, went to the making of this book! Some men go [to] the North Pole to do things-some go to wars - some trade and swindle: we just stayed where we were and made a book!" After Walt calmed down, Horace ventured, "That's your best printing so far." The poet agreed, but with one poignant exception, "So I should say myself, except, perhaps for the " 55 edition" (2:293-294).

Some time later Whitman fondly reminisced about that edition: 
"It was in green back—-dark green — mottled — rough—-large gilt letters" $(6: 4)$. To be sure, the poet was not about to let sentimental attraction to his first-born Leaves distract from the mature masterwork. When he heard a friend had set out to hunt down a copy of the 1855 Leaves, which was by 1889 a relatively expensive proposition, Whitman was emphatically discouraging: "Tell him not to-tell him it's not worth while - not worth the powder . . . it costs 20 dollars . . . Yes, yes-tell Tom not to. It is held at a ridiculous figure. Why, I should think a fellow would want the last book [i.e. the Complete Poems and Prose] - the last edition-the full edition-complete" (6:4). Some months later, Whitman waxed bemused over the high prices paid by collectors for early Leaves editions, having seen an English catalogue offering rare and autographed copies for a dozen pounds: "I wish I had a few hundred of the books myself now-they would set me up! When I did have them, no price was low enough to persuade the world that they were to be desired!" (6:385).

A poignant vignette unfolded on the evening of October 7, 1889, before a "wood-fire burning lustily." Traubel dropped by with a copy of Whitman's 1871 After All, Not to Create Only (the poem was later titled "Song of the Exposition"), newly bound by McKay. Whitman handled this thin book from his fairly distant past, admiring it: "It is wonderful neat - wonderful! How healthy the print! — the big clean type! . . . This is my design - I conceived it - it has a good familiar look, after a long absence." Whitman then began to brood when Traubel guessed that McKay had bought all the unsold sheets of After All at auction; then Whitman vouchsafed a shocking proposal: "I have been thinking, Horace, I should myself like to sell out bag and baggage to Dave-sell him all I have here, copyrights, everything - with permission, at any rate, to publish, ad libitum, to the year 1900 . The time has come to me to unload. I shall kick the bucket soon-very soon." Clearly stunned (Whitman had hitherto rejected all proposals for a complete sell-off), Traubel noticed that Whitman's voice was "quite strong, though the tone rather more sad than I had known it for a long time." Then Walt urged Horace to broach the matter with McKay. "As it is now he is in my power: I could clap down on him in an hour-stop him outright. It is a serious turn for me all around." Horace kept the following thought to himself: "Gloomily he talked. Whereas before he has fought all notion of making even a five-year's contract with McKay, now comes this. Unless he urges it again, I shall say nothing to Dave. My personal feeling is strong against a precipitate step, as this would be" $(6: 48)$. Doubtless to Traubel's relief, this notion of drastically relinquishing artistic control over the manufacturing process apparently did not resurface.

The firm exercise of artistic control evoked some by no means 
tedious printerial conniptions running up to the publication of the "deathbed" edition. Referring to this crowning volume, Whitman said, "It is a closing act - the last on the bill: soon the curtain will be down" (9:9). This closing act indeed had its drama, if only because Whitman's precipitous physical decline during his last fall and winter, combined with the tendency of McKay and Oldach to behave like cold molasses, created a real sense of urgency. Matters were made worse when both firms began to focus on Christmas-related print jobs. In mid-October 1891, Whitman griped, "I am getting riled about Leaves of Grass. Dave is delaying us inexcusably" (9:35).

And then Whitman had to fight a double battle with McKay to convince him both that the added pages of "Good-bye My Fancy" would not make the book unwieldy and that the price of the paper and bound editions should be kept down to $\$ 1$ and $\$ 2$, respectively. The showdown came when McKay came to Mickle Street on October 20, 1891. Here is Whitman's report: "Dave was here . . . having a long talk with me. The upshot of it all being, that the book will take in the new pages and remain in its present shape, for its present price-a facsimile autograph to go on the title page. Dave fought me like the devil on that dollar edition-would not have it on any terms. And what do you think he suggests? Why, that if we have a dollar edition, then let's set the other at four dollars. Which I would not hear to at all-no, no!" (9:58).

A month later, in November, McKay was almost ready to send over a sample stitched copy with the annex pages, but he harbored dark suspicions. Horace thus told Walt with a laugh, "Dave declares the book's getting too big, and worse still, that you will add more pages before you are through." Walt promised, "No, not a page. I am done-the last seed is set out" (9:138).

Finally, on December 5, the first sample stitched but unbound copy arrived. Traubel writes, "He took the first book eagerly-turned it over and over-looked at it, at me, murmuring, 'After hard labor and long waiting, here it is, yes, here it is! . . It is a long story, isn't it? And here we are, at its end, heads above water!' " (9:206). Now, a couple years earlier Whitman had occasion to remark, "It is a saying among the proofreaders that there never has been a book without a mistake - never - never - from the earliest records of printing: never a book absolutely correct-technically, mechanically" (2:324). Well, this joyous moment was no exception. Horace asks if Walt has noticed the "miserable misplacement" of the facsimile autograph on the title page: "Yes I did-it is very bad, very. Though whether put there out of bad taste or for publisherial reasons I can't say. Either way, it is horribly mal" $(9: 206)$. Still, the author was pleased enough to send a copy immediately to Dr. Bucke for his approval. On December 10, the poet regained 
his buoyant spirits; he had a philosophical attitude about water under the bridge. He reported to Horace that Bucke "says he likes it - that it satisfies him. And it satisfies me, too ... It is a very happy job. Oldach, the fellows over there, are to be congratulated" $(9: 218)$.

The seven-week wait to gloat over the final bound version of what was now referred to as "the green book" must have been excruciating. On January 19, Horace stopped by to say the book would arrive in two days, and Whitman remarked, "You can hardly imagine how much my curiosity is aroused. I can hardly wait for the book: I am as wild and eager as a child" (9:358-59). Not two days later but four, Horace was able to place the green book in the hands of a seriously declining poet. Examining it by candlelight in his bed, his mood was more elegiac than exuberant: "This, of course, is the edition I swear by" (9:379). And then he suggested two changes of the stamping on the cover. First, he desired Leaves of Grass to become Walt Whitman's Leaves of Grass. Second, he asked that the phrase "Complete ' 92 " be altered to give the full fournumeral date and be printed in big, bold type. He explained, "This is to be in future the only authentic and perfect [edition]. And I want to make that evident-evident not casually, but radically." The next day he refined the change, asking that "Complete" and "1892" be put on separate lines and the date should be "in a big figure which nobody can mistake. That damned thing as it stands now-the curl [of the apostrophe] and the 92 .. nobody will understand" (9:381-382).

After condemning the tiny apostrophe, Whitman leapt on his high horse and offered this resounding ave atque vale for his last, emphatically "physical" book: "This is now my own personal, authenticated volume - sealed, signed, made as it stands, by me, to so remain, if I can keep it, forever and ever. It is my ultimate, my final word and touch, to go forth now, for good or bad, into the world of the future. It is from this deep-yes, profound-conviction that I hope now, before I go, to see an actual physical book before my eyes, shaped and left to the last particular just as I, its author, the immediate person most concerned, approve and assent for its own." At which Traubel exclaimed, "I wish all that could be set forth in the advertisement. It would be a blazing sun" (9:382).

Four days later, on January 27, Whitman said that he had yielded to McKay on his first bright idea, presumably because the facsimile autograph makes Walt Whitman's Leaves of Grass redundant. But on the bold "1892" he was adamant, calling this edition "the concluding and rounded utterance of my life, of my faith," then adding, "It is for this reason I wish the '1892' bold on the cover-bold-unmistakably" (9:394).

What happened? Well, on January 30, a day after Traubel learned 
that Whitman's obituary was already set in type, a corrected "green book" passed muster- "I like it, like it - it presents a fine appearance"but even by candlelight and amid hiccoughs the poet's sharp eye was offended. Traubel records, "His eye caught an almost indistinguishable curl on the ' 8 ' in ' 1892 .' [The apostrophe had apparently not been removed when the date was rendered as four numerals.] 'I don't like that,' he said critically." Then he recognized the lack of a bold "1892": "In spite of my request for an antique or black letter, Dave has carefully avoided them." Too worn to fight, Whitman said, "But never mind-I am grateful enough to have it done-to see it" (9:405).

On February 1, Traubel writes, "In afternoon to see McKay, who will follow W.'s instructions as to spacing of stamps, though he would probably prefer no such radical change" (9:409). Weeks passed, and on February 18 Horace was disappointed to find no final version of the green book to show to Walt. When it finally arrived the next day, Whitman was laid too low to look at it, but on February 22 he examined it and experienced what I believe is the last printerial aggravation of his life. All the changes he had asked for had been made, but for one: "complete" and "1892" remained on the same line. "Half-twitted, half smiling," Whitman's reaction, referring of course to McKay, was this: "Bound to have his own way!" (9:480).

A few weeks later and just ten days before he died, Whitman made his last book-making decision, one that, I happily report, was followed. Traubel asked, "You wish Dave to use a thinner paper in the new edition of Leaves?" Whitman replied amid labored breathing, "Yes, that is my idea, but I leave the final decision to him" (9:550). A few days later, Traubel records that he saw McKay and "found he was rather disposed to assent to W.'s proposition for paper of lighter weight" (9:563).

A minor happy ending. But I feel I may be leaving the impression that Whitman's book-making aesthetic was substantially foiled by dogmatic, frugal, or timid publishers, draggy binders, and slouchy workmen. That was not the case. By and large, the poet was humored in what he referred to as his "pranks" as a book designer. He admitted as much one day, after fuming over the "blotchy" proof of a title page he had received from Ferguson. Putting his immediate annoyance in perspective, Whitman solaced himself: "I think that if ever any man should be satisfied in having had his own way pretty much through life, that man is me, Walt Whitman" (5:144-45).

\section{A BRIEF ANNEX}

As one of Whitman's three literary executors, Traubel continued for many years to be involved in the making of Whitman books-and in 
sarcastic sniping at Whitman books made by others of which he disapproved. I cannot resist offering a few highlights from the many articles on book manufacture that Traubel published in the Conservator, for they show-and there is no surprise in this at all - that the Whitman aesthetic of the book survived long after the poet entered Harleigh Cemetery.

An example of Traubel holding high the torch of Whitman's book aesthetic is his heartfelt review of a 1912 edition of the four "Memories of President Lincoln" poems, along with the Gettysburg Address and other matter. The volume came from the prolific and distinguished printer Thomas Mosher of Portland, Maine. It delighted Traubel: "The book's a beauty. And yet it's an accessible book. It's not held back for rich collectors." Traubel then vents his spleen at publishers who produce small runs of expensive editions:

Barnum said the people liked to be humbugged. Publishers often apply Barnum. They issue an everyday book for two or three dollars. They put a few cents more in paper and offer an edition at ten dollars. They put a little extra tooling on the ten dollar edition, give it another name and put it up at twenty dollars. They buy a piece of manuscript for fifty cents or a dollar at auction and add it to the twenty dollar edition which they sell for fifty dollars. They print a certain number of copies on India paper or Japan vellum and splash some color on the portraits and print the headlines in red instead of black ink and sell copies of it to the hundred thousand dollar men for two hundred and fifty apiece. You'll think this is the limit. But it's not. The millionaires are still to be reached. . . . So they add a few dados of one sort or another with perhaps a half dozen or dozen pages of the author's manuscript scattered through the book.

Mosher provides an admirable contrast, in Traubel's view: "Mosher has made it possible for you to love the bookmaker as well as the bookwriter. Not by making one beautiful book at a thousand dollars. By making a thousand beautiful books at one dollar." Traubel then cites two of his own long-held printerial credos, which are pure Whitman: "The test of the printshop is not whether we can make something ugly and worthless with sixty-three-cent paper but whether we can make something beautiful and worthwhile with ten-cent paper. . . . The test of the printshop is not whether we can do something magnificent as an aristocrat but whether we can do something simple as a democrat." Traubel concludes his review, "Mosher triumphs in both tests. He hasn't made the beautiful common. He has made the common beautiful" (November $1912 ; 23: 196) .{ }^{6}$ Walt, who found even a $\$ 4$ Leaves hard to swallow in 1891, would have been pleased too.

What made Traubel very cranky, on the other hand, were what he called "piecemeal Whitmans," the editions put out by unscrupulous publishers that purported to be the complete Leaves of Grass but weren't. Traubel's expressions of outrage on the subject are so frequent in the Conservator that they become amusing. He expressed his executo- 
rial credo most eloquently, perhaps, when he announced in 1917 that Doubleday, Page \& Company would become the new official Whitman publisher, taking over from Mitchell Kennerley: "Leaves of Grass is not a fragment of a book but a book. It's not a desultory collection of poems but a poem. It belongs together as Whitman arranged it, the very last line with the very first line ... Any issues of Whitman done in contravention of his known theory of the vital sequence of the poems is therefore a misrepresentation" (August 1917; 28:92).

On the other hand, Traubel was perhaps too eager for Whitman to gain his "foothold" as America's preeminent poet to stand in the way of all the Walt Whitman, funiors that began to proliferate. With the first of the twentieth century's numerous illustrated "piecemeal" Leaves beginning to appear, Traubel turned art critic. One of my favorite items in Conserving Walt Whitman's Fame is his review of a 1913 volume published by E.P. Dutton in New York and J.M. Dent in London titled Poems from Leaves of Grass. The big, handsomely bound book offers about 200 poems, but the special interest is the twenty-four color illustrations by Margaret C. Cook. They are most remarkable because there is full nudity and not a stitch of clothing on any of the figures represented in them. A few of the illustrations feature a pair of young men clearly represented as lovers. Traubel's review is not only a rave, but also one of the countless paraphrases of the fundamental "purports" of Leaves that appeared in the Conservator. Here are a few of its highlights:

One thing it [i.e. Leaves of Grass] dont know what to do with is compromise. . . . That's where Margaret Cook is strong. She got onto the Whitman impulse. No compromise. So her work from first to last is consistently noble. She knew Leaves of Grass couldn't be illustrated by literalism.... [S] he betrays no uncertainty. She dont waste herself in any vain gestures. She made up her mind and stuck to her last. Whitman wrote a root book. She found in it the inspiration for these root pictures ... She has used color. She has used nudity. She has used freedom ... So far as I know this is the first pictorial treatment of Leaves of Grass on its own plane. I have seen nothing certainly that goes above it. I have seen much that was below. Margaret Cook has scaled the lookout . . .[S]he [has] seized the spirit of its unhesitating summons." (May 1914; 25:43)

In conclusion, I would like to quote from a 1917 Conservator article in which Traubel boasts of Whitman's approach to universal acceptance. He quotes an acquaintance, John Phillips, as saying, "Whitman has ceased to be a speculative personality. He's an accepted equity among the classics of the world." Obviously sharing this view, Traubel reminisces about predicting to Whitman that the value of old Leaves editions would rise immensely: "He got a heap of fun out of my frequent assertion that I expected to live to see him sold for fifty dollars a volume. I did live to see it" (August 1917; 28:93). If Whitman were alive today, I trust he would get a heap of fun out of learning that, in the fall of 2005, 
at two of New York City's most eminent rare book shops on Madison Avenue, the "big book" of 1888, autographed by both Whitman and Traubel, was on offer for $\$ 15,000$, and a first edition of Leaves of Grass was priced at $\$ 150,000$.

Hunter College

\section{NOTES}

1 G. Thomas Tanselle, The Life and Work of Fredson Bowers (Charlottesville: Bibliographical Society of the University of Virginia, 1993); Fredson Bowers, ed., Whitman's Manuscripts: Leaves of Grass 1860 (Chicago: University of Chicago Press, 1955).

2 Intimate with Walt: Selections from Whitman's Conversations with Horace Traubel, 1888-1892 (Iowa City: University of Iowa Press, 2001), 89.

3 My anthology, Conserving Walt Whitman's Fame: Selections from Horace Traubel's Conservator, 1890-1919, has since appeared as part of the Iowa Whitman Series, edited by Ed Folsom (University of Iowa Press, 2006).

4 All citations from Horace Traubel's With Walt Whitman in Camden (various publishers, 1906-1996) will be given in the text, volume number followed by page number.

5 "Printerial" is a typical Whitman coinage; see, for example, his use of the word in With Walt Whitman in Camden, 1:171.

6 Citations from the Conservator give the month and year of publication, followed by the volume and page number. The review of Mosher's edition can be found in Conserving Walt Whitman's Fame (212-213), along with the review of the Leaves illustrated by Margaret C. Cook discussed below (213-214). 